\title{
Partners in Writing and Rewriting History: Philanthropy and Higher Education
}

Received (in revised form): June 14, 2007

\section{Shelley Strickland}

is a doctoral student in higher education at the University of Michigan and a research associate in the National Forum on Higher Education for the Public Good. She has more than a decade of experience in university advancement.

\begin{abstract}
Hearkening back to the historic relationship between philanthropy and higher education is useful for two reasons. First, it allows us to examine history in a more complete context. Second, it allows us to draw contemporary parallels. Rather than building institutions, today's transformational donors appear interested in how institutions build communities. While further research is needed, connections between the motives of today's donors and the outlets for their giving seem to indicate an opportunity for affecting change in the academy's internal operations (including those of development), and in making a transformative impact on the institution's role in society. International Journal of Educational Advancement (2007) 7, 104-116. doi:10.1057/palgrave.ijea.2150051
\end{abstract}

\footnotetext{
Author's Contact Address:

Shelley Strickland

National Forum on Higher Education for the Public Good University of Michigan

2339 School of Education Building

610 E. University Avenue

Ann Arbor, MI 48109-1259, USA

Phone: +1 7346158882

Fax: +1 7346159777

Email: srstric@umich.edu
}

\author{
Keywords: \\ transformational gifts, donor \\ motivations, higher education \\ philanthropy
}

\section{Introduction}

Given the magnitude and visibility of today's major donors, scholars have recognized this as a new era for philanthropy (Blackman et al., 2000; Tempel, 2003; Tomkins, 2006). Gates, Buffett and other contemporary philanthropists are often contrasted with Carnegie and Rockefeller (Nielsen, 1996; Blackman et al., 2000; D’Souza, 2001; Marcy, 2001; Wagner, 2003; Tobin, 2006; Tomkins, 2006; Hrywna, 2006; Allen, 2007; Donnan, 2007). Some scholars see similarities in the philanthropists and in their motives for giving, while others argue differences (Nielsen, 1996; Tempel, 2003). One thing seems certain: there is agreement that this is the largest concentration of wealth in the hands of a few since the last defining period in American philanthropy a century ago (Nielsen, 1996; Blackman et al., 2000; Wagner, 2003; Tempel, 2003; Katz, 2007).

This continued comparison of current and historical philanthropy is 
important for two reasons. First, it allows for a revision of history to include and highlight those whose stories have been ignored or marginalized. Second and most importantly, contrasting today's donors provides an opportunity to create a new history of educational philanthropy. While past major donors largely built institutions, current major donors are transforming them.

This paper will use the context of history to inform and frame an exploration of contemporary philanthropy for higher education and how current donors are using transformational gifts to reshape institutions-institutions that are poised for or are already exhibiting engagement. Implications for attracting transformational gifts are then presented.

\section{History of Higher Education Philanthropy-An Overview}

Pairing the names of donors and the institutions they created constitutes an expedient-and monumental-history of educational philanthropy in the United States. As a Council for Aid to Education guide for potential philanthropists explains: "Some of the largest donors will be familiar to you: Leland Stanford, James Buchanan Duke, John D. Rockefeller, and George Eastman, who were instrumental in developing Stanford, Duke, the University of Chicago, and both the University of Rochester and MIT, respectively" (Caulkins et al., 2002, p. 3). Blackman et al. claim, "America's intellectual infrastructure was donated by philanthropists" (2000, p. 50).
Indeed, the traditional philanthropic history of education is largely about what was created and a few facts about what prompted donors to act. The story is familiar to many, for example: Stanford became the West Coast equivalent of Harvard because in California Senator Stanford and his wife could create a new institution to memorialize their son (Nielsen, 1996). America's first university, modeled after the renowned German research universities (Gaudiani, 2003), bears an unlikely and unusual name in honor of its major benefactor.

Yet, institutions we credit to white male donors do not tell the full story of educational philanthropy. For example, one of the reasons Johns Hopkins University is a premier institution rests on the reputation of its medical school and its historic commitment to community. Those hallmarks owe their existence to a philanthropist who is not a household name. Mary Garrett gave what can only be termed a major gift to Johns Hopkins on two stipulations: that medical education be reconstituted as a graduate program rather than an unstructured curriculum and that women be admitted to the school (Gaudiani, 2003). It was also a woman who created essentially the country's first educational scholarship. While Harvard's first president is cited as an example of presidential fund raising for his role in securing a major donor (Cook, 1997a), the partnership of President Thomas Weld with Lady Anne Mowlson shows her motivation to assist others and enhance community (Gaudiani, 2003).

These examples illustrate that scholars, if not intentionally neglecting the field, are still struggling to explore 
a history that ventures beyond the big names, whether names of philanthropists or institutions. A recent provocative work edited by Andrea Walton boldly asserts this very premise. "Despite the long list of women's philanthropic engagements, until recent decades women have been virtually absent from dominant accounts of US philanthropy and remain excluded from, or at best marginalized in, the literature on educational philanthropy" (2005, p. 2). Her introduction provides a useful and comprehensive look at higher education philanthropy in general, as she summarizes the research and illustrates the oversights. Her account is also telling of the large gaps in the educational philanthropic literature in general.

When the seminal work on educational philanthropy, Sears' Philanthropy in Higher Education, was republished-nearly 70 years after its initial publication-it was with the hope that his work and the larger field of scholarly research on philanthropy would finally receive the audience and attention both deserve (Sears, 1990). After Sears' seminal account, it is several decades before Curti takes on the topic and his joint work with Nash is largely the most recent historical overview (Walton, 2005).

While Shaw and Taylor (1995) have literally rewritten the book on reinventing fund raising, their influential work could also be considered a revision of educational philanthropy. They trace the history of women's philanthropy, which includes education as a priority and benefited not only schools and colleges for women but also male institutions, even though these gifts were not always properly valued (Shaw and Taylor, 1995).

Better understanding history becomes critical for understanding the history being made by today's major philanthropists. While there will always be exceptions, the main difference between historical donors and today's major philanthropists is in the extent of their involvement they wish to have on the institutions they support. In reviewing the next major follow-up to Sears' work on educational philanthropy, Philanthropy in the Shaping of American Higher Education by Merle Curti and Roderick Nash, Bremner highlights their concluding finding that the optimal donor relationship extended little beyond giving money (1966). Today's major donors are creating a new breed of philanthropy precisely because of the engagement and involvement they expect and demand.

\section{A New History of Higher Education Philanthropy}

In arguably the most comprehensive research on transformational giving, which they define as big or major gifts distinguished by "their unique capacity to alter the programs, perceptions and future of an organization," Kay Sprinkel Grace and Alan Wendroff (2001, p. 15) explain that the concept of transformational giving "was first applied to large gifts that were given to public universities in the United States by private individuals and foundations. Few in number, but large in impact, these gifts marked a sea change in private support of public institutions. This significant shift-from 
believing that public higher education was supported by tax dollars alone to realizing that the public institutions of a state were institutions deserving private investment-occurred in the last several decades" (Grace and Wendroff, 2001, p. 3). Indeed, this blurring of lines between public and private would have been foreign to Carnegie and Rockefeller. They distinguished philanthropy and business as separate practices, even while the crossovers are complex and distinctive (Clotfelter and Ehrlich, 1999).

While transformational gifts are not limited to educational institutions, colleges and universities have been the focus of such giving, likely because donors have seen the institutions as places with a breadth of services and a complex infrastructure to implement and maximize the potential of transformational gifts (Grace and Wendroff, 2001). Of the mega-gifts in America between 1995 and 2000, gifts of $\$ 10$ million or more, higher education received the most of any sector, with 56 percent of all gifts or $\$ 10$ billion dollars total (Tobin et al., 2003). In summarizing the major gifts literature, Cook found that belief in mission, organizational prestige, and interest in a certain area were primary donor motives for major gifts. "Lowprestige institutions occasionally receive major gifts-even unrestricted ones-from someone giving out of community pride or loyalty to alma mater or gratitude or desire to make a difference or because of the influence a doctor or nurse or social worker or professor had on his or her life (e.g., the $\$ 100$ million Mr. and Mrs. Henry Rowan gave to Glassboro State College [now Rowan College] in New Jersey)" (Cook, 1997b, p. 13).
The amounts of such gifts are staggering and have brought philanthropy to the attention of not only researchers and scholars but also the media as well. "Philanthropy is hot," Shawn Donnan recently wrote (2007, p. 16). Grace and Wendroff are careful to note, however, that transformational giving is not new. Whether in America or abroad, "What most of these gifts had in common, relative to their origin, was that they came from traditional sources of philanthropic giving: wealthy families with a strong commitment to give back to the community, like Carnegie, Rockefeller..." (Grace and Wendroff, 2001, p. 85).

\section{Transformational Donors}

The contrast to Carnegie and Rockefeller largely ends there. While those historical philanthropists created institutions, today's major donors are transforming them, just as they are reshaping philanthropy (Blackman et al., 2000). The new philanthropists have affected the nonprofit world with their business practices and emphasis on process, results, and evaluation (Conlin et al., 2003).

Grace and Wendroff write that many of today's donors represent changing demographics from historical philanthropists. They include "the cyber and venture-capital rich; women; ethnic and racial groups previously underrepresented or under-recognized in philanthropy; and those who have become wealthy through the intergenerational transfer of trillions of dollars" (2001, p. 86). Regardless of whether they represent a continuation of generational philanthropy or someone new to giving, the "new 
philanthropists" share seven characteristics:

- Their first gift is often a major giftthey may not grow through the giving pyramid like traditional donors.

- They invest in issues and expect results.

- They seek values-driven organizations, often without realizing that it is the values that are attracting them.

- They want organizations to accept their ideas and opinions, not just their money.

- They are impatient for results.

- They may be impatient for the ask.

- They want to be involved, and often want a base of power or control in the program or organization (Grace and Wendroff, 2001, p. 87).

While they made their money quickly, today's donors take a considerable amount of time to research an organization (Allen, 2007). Today's donors create rather than just donate to philanthropic endeavors (Schervish, 2005). In addition to often seeking out the institutions they want to support (Grace, 1999), philanthropists are setting up foundations (Wagner, 2003) but spending out the resources during their lifetimes when they can actively address pressing societal issues (Conlin et al., 2003).

Not surprising to those understanding history, today's new philanthropists are more likely to be women or to engage in a more "female style" of giving, more reminiscent of a mother's than a father's philanthropy, Grace believes (1999). To be sure, the research of Shaw and Taylor found that women are motivated by implementing change rather than preserving the status quo: "Not once in the past six years have we heard a woman mention that her gift was prompted by a desire to perpetuate an institution" (Shaw and Taylor, 1995, p. 185).

"Gifts of significance are given to organizations that earn the trust and confidence of benefactors," Hodge declares (2003, p. 90). He enlists a new paradigm for the donor relationship, which has moved from the transactional state of giving, through the transitional stage of naming to the transformational stage of changing, where donor and organization are truly partners. One of the critical differences between transactive philanthropy and investment philanthropy is accountability, which has always been desired but is now of primary importance (Wagner, 2003).

It is important to note that while headlines and references abound in both scholarly and popular literature to transformational giving and positioning current donors as the new Carnegies and Rockefellers, the research on today's major donors is still emerging (Prince and File, 1994; Grace, 1999; Tobin et al., 2003). Tobin and associates conclude that mega-gifts of $\$ 10$ million or more "have been the subject of individual accolades rather than systematic study" and that "little research has been done to understand the mega-gift or the mega-donor" (2003, p. 10).

Since research on transformational donors is yet developing, it should not be surprising that research on the recipients of these donors' gifts and how these institutions are affected is also needed. In reviewing the literature on major gifts, Cook noted that while 
much has been written about donor motives as well as on organizational prerequisites for major gifts, what is not as obvious is the critical interaction or intersection of donor motivations and institutional readiness (Cook, 1997b).

Looking at what motivates and attracts today's donors-and at institutions that have benefited from their largesse-helps to construct an argument that the common element between the two is a desire for engagement.

\section{Transformational Gifts and Engaged Institutions- Implications}

Clearly, transformational gifts involve extensive engagement with the donor and expectations that the institutions will engage a community (or a social challenge) beyond the campus. The $\$ 150$ million gifts to Stanford University from entrepreneur Jim Clark (who founded several companies, including Netscape) was the result of three years of planning and conversation, much of it electronic (Grace, 1999).

When members of the Walton family, through the Walton Family Charitable Support Foundation, gave $\$ 300$ million to the University of Arkansas in 2002, which was then the largest donation ever to a public university, they were careful that it not be termed a "gift." Rather than gifts, the Waltons "make investments in people and places they are passionate about, and only after they have thoroughly vetted the investment risk and been assured they will be part of monitoring its success" (Strout, 2004, p. A24). The investment was intended to transform not only the institution but also the state through improving its flagship university and positioning education as a key to economic vitality.

The Council for Advancement and Support of Education (CASE) president John Lippincott believes the Waltons exemplify today's philanthropists, who want to actively engage in the gift's implementation and adherence to its intentions (Strout, 2004).

Grace and Wendroff (2001) believe there are eight common elements of all transformational gifts. Among these:

- Transformational gifts have an impact on the organization, its constituency, the donor, and the community.

- A gift's designation as transformational often has much to do with how it is cultivated, solicited, and stewarded.

- Transformational gifts are more than gifts; they are investments.

- Gifts are motivated by shared values between the investor and the organization.

- Gifts are rooted in a belief in the importance of the organizations' mission, and increasingly, they are issue driven.

- Donor-investors expect solid return from two bottom lines: the return on values, and the management of their investment (Grace and Wendroff, 2001, p. 21).

Tobin proclaims mega-gifts "are often donor designed to make a breakthrough-creating new organizational settings to improve society or an experiment in societal development. Often the mega-gift represents the beginning of a trend or direction in philanthropy" (Tobin et al., 2003, p. 10). Rather than 
waiting to create a legacy, for example, today's donors want to affect change in their lifetime (Wagner, 2003).

Because of these expectations, today's philanthropists can prove challenging for higher education. Established institutions might be viewed with suspicion (Marcy, 2001). Supporting the endowment may be seen as perpetuating the status quo. Because the new donors invest in issues, loyalty to a particular college can be less compelling than a cause. Long-term relationships can be harder to maintain, as the donor's interest must be cultivated through continuing progress on a given issue, even requiring benchmarks to be met for pledges to be fulfilled (Marcy, 2001). She also finds that the new donor is more willing to take risks and to support innovative ideas, such as an interdisciplinary program.

According to Jamie P. Merisotis, president of the Institute for Higher Education Policy, foundations, the vehicle of giving for many of today's donors (Wagner, 2003) “are increasingly interested in innovation and broad, replicable program development, as compared with the history of philanthropy in higher education, which has been more focused on bricks and mortar and curriculum development" (Pulley, 2002, p. A28). In fact, higher education could still be the beneficiary of grants but as a venue for achieving other goals (Pulley, 2002).

Perhaps it is time not only for a revision of the history of higher education philanthropy but also a time for institutions to recreate their very existence as well. Curti and Nash's historical treatise on educational philanthropy underscores the importance of private giving "to promote innovation in and reorientation of higher education" (Bremner, 1966, p. 177). That ability to affect change takes on a whole new meaning with today's donors. To interest the new philanthropists, institutions "can identify innovative and emerging projects at our institutions, and seek funds from new donors to support those efforts, taking advantage of their desire to support meaningful change while remaining true to an institution's mission and vision" (Marcy, 2001, p. B13). What are the implications of transformational gifts for higher education institutions?

\section{Changing the Academic Culture}

Although higher education should owe a debt of gratitude toward donors, the academy tends to have a suspicious attitude toward philanthropy. Faculty in particular can be skeptical or even condescending toward fund raising (Elliott, 2006). In challenging the proliferation of naming rights on campuses, even while acknowledging their historical roots, Altbach alleges the branding emphasis threatens an institution's commitment to truth and knowledge (2006).

While D'Souza concedes some of the distrust toward those benefiting from capitalism is concern for social justice, he believes academic prejudice is fueled by a fundamental lack of knowledge regarding entrepreneurism (2001). Adding to that misunderstanding is a fundamentally different mode of operations between the academy and today's donors, many of whom made their fortunes in the high-tech industry. 
"They move fast, while in the academic world speed is considered a sign of superficiality...Entrepreneurs take a lot of risks, looking to the prospect of gain, while academics are famously cautious, calculating what they stand to lose. Finally, entrepreneurs are gregarious and typically have the capacity to build teams and motivate others. Those qualities are rare in the academic world, where narcissism is in abundant supply and achievement is usually the result of individual excellence" (D'Souza, 2001, p. B14).

The academic world can articulate needs but does not always take advantage of opportunity. As might be expected, the Waltons' transformational gift to the University of Arkansas was initially met with suspicion: "Early on I think that there were members of our academic community who misunderstood the purposes and potential impact of the gift," explained Bob Smith, then provost, vice chancellor for academic affairs and interim dean of the honors college (Strout, 2004, p. A24). Tobin argues that Warren Buffett and Bill Gates can only be philanthropists precisely because our society allows them to become ultra-wealthy (2006). In writing Who Really Cares: The Surprising Truth About Compassionate Conservatism, Arthur C. Brooks argues that it is worth reconsidering our common stereotypes about who behaves compassionately in America today. As he recently wrote, "In particular, academics might benefit from a re-examination of some of its dogmas on this point" (Brooks, 2007, p. B13).

The academy must not condescend to donors, who might possess "entrepreneurial IQ" but not intelligence as measured "in the Ivy League sense" (D’Souza, 2001, p. B14). Because the new donors are interested in the intellectual process of arriving at comprehensive, long-range solutions, development officers must ensure that the intellectual ability of donors is respected (Wagner, 2003).

Marcy cautions that there probably needs to be a balance between accommodating the new donor and risking institutional autonomy (2001). "Innovations like learning communities and service learning show promise for improving the educational experience for students, but require financial support and major institutional change to be successful. When campuses need assistance with innovation, it is likely that the new donors will be the ones who respond with support and energy" (Marcy, 2001, p. B13).

To ensure that philanthropy continues to drive America's economic development engine as it has historically done, Claire Guadiani calls for more emphasis on service learning in institutions and partnerships with communities (2003). Given the entire system of faculty training and the current recognition and reward structure, promoting the scholarship of engagement and community impact will be problematic (Checkoway, 2001). Support for faculty research would help alleviate such concerns, and programmatic and endowed funds to implement engagement would allow for a shift in operations.

\section{Public Concerns and Messages}

Accountability is one of the challenges for twenty-first century philanthropy (Tempel, 2003; Hrywna, 2006; Katz, 
2007). Today's donors demand accountability and results (Blackman et al., 2000), which creates challenges for accountability (Wagner, 2003; Schervish, 2005) and also poses ethical challenges (Elliott, 2006).

The accountability is not just for outcomes but also for inputs. Large gifts have prompted questioning about the accrual of wealth and the need for big university endowments, especially with limited payouts (Gose, 2004). Some are increasingly questioning the control of wealth in the hands of so few (Tomkins, 2006; Jaschik, 2006). Indeed, Tobin recommends that philanthropy to colleges and universities be examined, as the top ten endowed universities have more dollars than the GDP of the 75 poorest nations combined (2003). In addition to some sectors being untouched by transformational giving, the focus of mega-gifts on higher education is encouraged by tax policies that allow institutions to accumulate large endowments, which he believes should be studied (Tobin et al., 2003).

CASE president John Lippincott believes the sheer size of highmagnitude gifts poses a public relations challenge for conveying the true economic challenges for higher education. "Colleges will need to constantly educate government officials that the need for public funds hasn't gone away and that the publicity surrounding the latest record gift for Harvard or Stanford has nothing to do with the economic realities of 99 percent of American higher education" (Jaschik, 2006).

An American Council on Education publication (2000) provides answers for many common donor questions, such as "Why should a donor give to a college or university with a large endowment as opposed to a charity in greater need of funds?" and "Why shouldn't there be a required or larger endowment spending required as foundations have?" (p. 11). Universities must explain that large gifts allow them to respond to greater demands, have the ability to weather funding challenges, and exist for perpetuity. Higher education serves the past, present, and future while helping society. Universities must articulate that they are seeking large gifts "for socially important purposes" (MSNBC. com, 2006).

\section{Role of the Development Professional}

While he is quick to note that Cornell must have "transformational gifts\$50 million, \$100 million-in that range-and we certainly will have that" (MSNBC.com, 2006), vice president for alumni affairs and development Charlie Phlegar also argues for transformational ideas. "We have to focus on big ideas, what I call transformational ideas, where you're not just making a gift for a building or for an endowed faculty position, but you're having an even greater impact on society" (Ju, 2006). These collaborative ideas with the potential to change the world in some way should be attractive to supporters at all levels (Ju, 2006).

John H. Zeller, vice president for development and alumni relations at the University of Pennsylvania, cautions that while transformational gifts are needed, donors must also understand why lesser gifts are meaningful. "The smaller gift, multiplied, really does have an impact. 
But it's hard for people to see that sometimes, when those things get lost in the announcements of seven, eight and nine-figure gifts" (Jaschik, 2006). In the "Importance of Fundraising" (cited in Cook, 1997a), former Cornell President Frank Rhodes argued: "Rather than making donors of more modest means feel that their own contributions are insignificant when compared to the need-as some higher education observers had initially feared-billion-dollar campaigns have opened up new levels of giving that campaign for smaller amounts might never have tapped" (p. 62). While pursuing major donors yields more immediate success, it will be at the expense of long-term results if smaller donors are ignored, warns CASE president John Lippincott (Jaschik, 2006), especially since average Americans are continuing to be generous (Blackman et al., 2000).

Development officers must also ensure that big ideas live beyond the current leadership. The chemistry between a venture philanthropist and the leader is critical (Allen, 2007). The Waltons' transformational gift to Arkansas did hinge on the chancellor, whom they asked to commit to the institutions for five years to see the gift through; although it was not part of the formal agreement, the chancellor wrote a personal letter to the foundation promising to stay (Strout, 2004). After Summers stepped down from the Harvard presidency, donors were hesitant "to give what the University calls 'transformational gifts' - an endowment of large magnitude, such as a building or other ambitious project-under [an] interim administration" (Rayman, 2006).
To help ensure that transformational gifts occur, "As agents of change, development professionals and volunteers must be involved at the highest levels of decision making...in creating the mission and moving the organization to greater levels of efficiency and effectiveness" (Hodge, 2003, p. 94). In addition, development officers must help donors to understand the potential impact of their giving. "For the most part, the philanthropic community has not initiated effective strategies to persuade the financially well-off to make philanthropy the positive cornerstone for innovative and efficient production of social outcomes" (Schervish, 2005, p. 83).

To be sure, transformational donors are attracted by the issues, ideas, and values inherent in the mission and should measure value in terms of the people served and lives enhanced (Grace, 1999). After studying contemporary funders, Peter Frumkin argues for a revision of the logic behind philanthropy: it must simultaneously meet public needs while expressing private beliefs and commitments (2006). Development officers have the opportunity to help donors forge their moral identity through a socially beneficial endeavor (Schervish, 2005). "Many prospective major benefactors know how to accumulate 'means' but not 'meaning' in their lives. One way of looking at major gift work is that development officers, volunteers, and donors are on a long walk together to find meaning in life. Meaning can be found through philanthropy" (Hodge, 2003, p. 96). Women, and one could argue the new donors who follow many of those giving patterns, will help fundraisers to 
reexamine their reasons for being (Shaw and Taylor, 1995).

\section{Need for Further Research}

The donor motivations outlined in The Seven Faces of Philanthropy (Prince and File, 1994), the decisive study of affluent donors based on empirical analysis of a large data set, would provide a useful context for further examination of major donors at the highest levels. "Transformational gift" has entered the lexicon since that publication but clearly some of the motivations for giving back to community and philanthropy as good business would apply to transformational donors. The interest the authors identified of affluent donors in establishing private foundations has proven to be prescient. Prince and File also noted that major donors did not feel organizations were leveraging their social networks to capacity and called on development professionals to empower the philanthropist through involvement, participation, and integration-all hallmarks of current top philanthropists.

Tobin's call for more research on mega-gifts, both donor motivations and gift recipients, has already been noted (2003). Jerold Panas has answered the call with a study of mega-donors that was not reviewed for the purposes of this paper but has been acclaimed as an important and missing contribution to the field, as it draws upon interviews with both donors and development professionals. His earlier work was cited by Prince and File (1994) in their pioneering book on affluent donor motivations. Clearly, there is still a need not only to better understand the donors but perhaps just as importantly the institutions receiving transformational gifts.

\section{Conclusion}

Private support has played a critical role in higher educational institutions historically, and postsecondary institutions were created to help promote the public good. Historical philanthropists helped ensure that an educated and enlightened citizenry would be part of a future society. By partnering with institutions committed to public engagement, today's philanthropists can write a new history of educational philanthropy and ensure that society benefits for generations to come.

Development officers play a critical role in the transformational process by helping higher education institutions adapt to a new culture, by recognizing the challenges for accountability and public perception, and by facilitating change through positions of advocacy within institutions and through a commitment to values-driven work in their own lives and the organizations they support.

\section{Acknowledgements}

The author wishes to thank Dr. John Burkhardt for his support and helpful suggestions on an earlier draft of this paper.

\footnotetext{
References

Allen, P. (2007), "Changing face of the big spenders," The Guardian, April 23, p. 3.

Altbach, P.G. (2006), "What's in a Name? For a million bucks or so, you can name that school," Academe, 92, 1, p. 48.

Blackman, A., Fulton, G., Jackson, D.S. and McLaughlin, L. (2000), "A new way of giving (The New Philanthropy)," Time, 156, 4, p. 48+.
} 
Bremner, R.H. (1966), "Reviewed works: Philanthropy in the shaping of American higher education by Merle Curti; Roderick Nash," The Journal of Higher Education, 37, 3, pp. 176-177.

Brooks, A.C. (2007), "Letters to the editor: Philanthropy in the United States, today and yesterday,"” The Chronicle of Higher Education, 553, 30, p. B13.

Caulkins, J.P., Cole, J., Hardoby, M. and Keyser, D. (2002), Intelligent Giving: Insights and Strategies for Higher Education Donors, RAND Council for Aid to Education, Santa Monica.

Checkoway, B. (2001), "Renewing the civic mission of the American Research University," The Journal of Higher Education, 72, 2, pp. $125-147$.

Clotfelter, C.T. and Ehrlich, T. (eds.) (1999), Philanthropy and the Nonprofit Sector in a Changing America, Indiana University Press, Bloomington.

Colleges seek to raise $\$ 4$ billion (2006, October 25), MSNBC.com.

Conlin, M., Hempel, J., Polek, D. and Dayton, T. (2003), "The top givers," Business Week, December 1.

Cook, W.B. (1997a), "Fund raising and the college presidency in an era of uncertainty: From 1975 to the present," The Journal of Higher Education, 68, 53, pp. 53-86.

Cook, W.B. (1997b), "Surveying the major gifts literature: Observations and reflections," Nonprofit Management \& Literature, 7, 3, pp. 333-347.

D'Souza, D. (2001), "Rich men, poor men, businessmen and scholars," The Chronicle of Higher Education, 47, 47, p. B14.

Donnan, S. (2007), "Philanthropy? He wrote the book," The Financial Times, February 24, p. 16.

Elliott, D. (2006), The Kindness of Strangers: Philanthropy and Higher Education, Rowman \& Littlefield Publishers, Inc., New York.

Frumkin, P. (2006), Strategic Giving: The Art and Science of Philanthropy, University of Chicago Press, Chicago.

Gaudiani, C. (2003), The Greater Good: How Philanthropy Drives the American Economy and Can Save Capitalism, Henry Holt and Company, LLC, New York.

Gose, B. (2004), "Philanthropic foundations face intense pressure to increase the amount they give to charities," The Chronicle of Higher Education, 50, 38, p. B12.

Grace, K.S. (1999), "Ten things you should know about transformational gifts," Contributions Magazine, available from http://www.contributionsmagazine.com/featured/ transformational.html.
Grace, K.S. and Wendroff, A.L. (2001), High Impact Philanthropy: How Donors, Boards, and Nonprofit Organizations Can Transform Communities, John Wiley \& Sons, Inc., New York.

Hodge, J.M. (2003), "Gifts of significance," in Tempel, E.R. (ed.), Hank Rosso's Achieving Excellence in Fundraising, 2nd edn., Jossey-Bass, San Francisco.

Hrywna, M. (2006), "Gates \& Buffett: transformational gifts can change the world," The Non-Profit Times, July 15.

Jaschik, S. (2006), "Endowment envy," Inside Higher Ed, October 12, available from http://www.insidehighered.com/layout/set/print/ news/2006/10/12/billions.

Ju, A. (2006), "Selling the 'transformational idea:' Cornell readies the launch of its capital campaign's public phase," Cornell ChronicleOnline, October 18, available from http://www.news.cornell.edu/stories/Oct06/ phlegar.interview.aj.html.

Katz, S.N. (2007), "Philanthropy's new math," The Chronicle of Higher Education, 53, 22, p. B6.

Marcy, M. (2001), "How to reach the new donors," The Chronicle of Higher Education, 47, 43, p. B13.

Nielsen, W.A. (1996), Inside American Philanthropy: The Dramas of Donorship, University of Oklahoma Press, Norman.

Prince, R.A. and File, K.M. (1994), The Seven Faces of Philanthropy: A New Approach to Cultivating Major Donors, Jossey-Bass, San Francisco.

Pulley, J.L. (2002), "Wealthy Atlantic philanthropies shift focus away from higher education," The Chronicle of Higher Education, 48, 25, p. A12.

Rayman, R.B. (2006), "Post-summers, large gifts in Limbo," The Harvard Crimson, June 7, available from http://www.thecrimon.com/article. aspx? ref=513817.

Schervish, P.G. (2005), "Major donors, major motives: The people and purposes behind major gifts," New Directions for Philanthropic Fundraising, 47, pp. 59-87.

Sears, J.B. (1990), Philanthropy in the History of American Higher Education, Transaction Publishers, New Brunswick.

Shaw, S.C. and Taylor, M.A. (1995), Reinventing Fundraising: Realizing the Potential of Women's Philanthropy, Jossey-Bass, San Francisco.

Strout, E. (2004), “It's \$300-Million, but don't call it a gift," The Chronicle of Higher Education, 50, 38, p. A24.

Tempel, E.R. (ed.) (2003), “Contemporary dynamics of philanthropy," Hank Rosso's Achieving Excellence in Fundraising, 2nd edn., Jossey-Bass, San Francisco. 
Tobin, G. (2006), "Buffetting megawealth: A lesson in philanthropy," National Review Online, July 6 , available from nationalreview.com.

Tobin, G.A., Solomon, J.R. and Karp, A.C. (2003), Mega-Gifts in American Philanthropy, Institute for Jewish \& Community Research, San Francisco.

Tomkins, R. (2006), "What's in it for them?," The Financial Times, September 23, p. 26.

American Council on Education (2000), Understanding College \& University
Endowments, American Council on Education, Washington, DC.

Wagner, L. (2003), “Trends in major donor behavior and innovative approaches to philanthropy," in Tempel, E.R. (ed.) Hank Rosso's Achieving Excellence in Fundraising, 2nd edn., Jossey-Bass, San Francisco.

Walton, A. (ed.) (2005), Women and Philanthropy in Higher Education, Indiana University Press, Bloomington. 